\title{
EQUÍVOCOS DA REDUÇÃO EQUITATIVA: A INDEVIDA SUPERPOSIÇÃO DE RESPONSABILIDADE CIVIL COM A RESPONSABILIDADE PATRIMONIAL
}

\author{
MISCONCEPTIONS OF EQUITABLE REDUCTION: THE IMPROPER OVERLAPPING OF \\ LIABILITY WITH ASSET LIABILITY
}

Daniel Bucar ${ }^{\mathrm{i}}$

Caio Ribeiro Pires ii

RESUMO: O presente trabalho pretende realizar uma revisão crítica das regras que introduzem a redução equitativa de indenização no direito brasileiro (art. 944, parágrafo único, e 928, parágrafo único, ambos do Código Civil). Inicialmente, sistematizam-se os posicionamentos doutrinários existentes sobre o tema e constata-se um compromisso majoritário no sentido de apontar o fundamento constitucional dos dispositivos. Após esta apresentação, revisita-se o conteúdo à luz da responsabilidade patrimonial, pouco estudada no Brasil e sempre de forma não organizada. Questiona-se, portanto, a corrente que examina o patrimônio do ofensor com o fim de quantificar a indenização, o que ocorre mediante a superposição da responsabilidade civil sobre a responsabilidade patrimonial, negligenciando a necessária análise coletiva do acervo patrimonial. Assim, propõe-se uma interpretação para os supracitados artigos da codificação civil capaz de harmonizá-los à axiologia do ordenamento jurídico.

Palavras-chave: Responsabilidade civil. Redução equitativa. Reparação integral. Patrimônio de dignidade. Reponsabilidade patrimonial. Concurso de credores.

\begin{abstract}
This article aims at a critical review of the rules that introduce equitable reduction of indemnity in Brazilian law. This is the sole paragraph of 944 , applicable to the assumptions of excessive disproportion between the severity of the fault and the damage, as well as the sole paragraph of art. 928, both of the Civil Code, which orders the subsidiary liability of the incapable, unable to materialize if they deprive these or their dependents of what is necessary to live. Initially, the existing doctrinal positions on the subject are systematized, what shows a great commitment to point out the constitutional foundation of the provisions. Thus, the current that values the offender's patrimony at the moment of the damage quantification is questioned, which occurs using a liability overlay on asset liability, neglecting a collective analysis of patrimony. After this the content is revisited in the light of the patrimonial responsibility, little studied in Brazil and always in an unorganized way. Finally, an interpretation is proposed for the aforementioned articles of civil codification capable of harmonizing them with the axiology of the legal system.
\end{abstract}

Keywords: Equitable reduction. Integral reparation. Patrimony of dignity. Property Liability. Credit Contest.

\footnotetext{
' Doutor e Mestre em Direito Civil pela Universidade do Estado do Rio de Janeiro. Especialista em Direito Civil pela Università degli Studi di Camerino (ITA). Professor de Direito Civil (Graduação e Pós-Graduação). Advogado e Procurador do Município do Rio de Janeiro.

ii Mestrando em Direito Civil pela UERJ. Graduado pela PUC Campinas. Advogado.
} 
SUMÁRIO: 1. Introdução. 2. Uma história de paralelos-paradoxais: trajetória da redução equitativa no Brasil. 2.1. O artigo 944, parágrafo único: reparação integral e perplexidades. 2.2. O art. 928: responsabilização civil, mitigada, dos incapazes. 3. Dos descaminhos na busca de um ponto de encontro: da "redução equitativa humanitária" à responsabilidade patrimonial. 3.1. Responsabilidade patrimonial no direito brasileiro: entre o resgate e a necessária sistematização dogmática. 3.2. Instrumentos de proteção, e reabilitação patrimonial, do ofensor superendividado na unidade do ordenamento. Redução equitativa: perspectivas na legalidade constitucional. 4.1. Responsabilidade (patrimonial) dos incapazes. 4.2. Redução equitativa por desproporção entre gravidade do dano e culpa: da mitigação ao reforço da reparação. 5. Conclusão. Referências.

\section{INTRODUÇÃO}

Apesar de o direto civil já ser objeto de uma reorganização geral, influenciada pela axiologia da Constituição da República1, algumas de suas disciplinas suscitam debates ainda mais candentes, advindos dos desafios inerentes à contemporaneidade e às reformas dogmáticas ocorridas. Definitivamente, é o caso da responsabilidade civil.

A matéria, que encontra em seu cerne questão jurídico-filosófica fundamental ("quem, em que condições e no âmbito de que limites deve suportar o dano"2), sofreu profundas alterações nas últimas décadas por força da massificação social, refletida em proporcional aumento de danos. Dois efeitos notórios, advindos deste movimento, foram a redução do papel da culpa e a especial atenção ao lesado, principalmente ao seu direito de ser indenizado ${ }^{3}$.

Este movimento é claramente perceptível no caminhar das fontes do direito brasileiro. Partindo do Código Civil de 1916, em que a responsabilidade civil era tratada nos artigos destinados a atos ilícitos (art. 159 e 160, CC), passando pelo dano moral timidamente reconhecido pelo Supremo Tribunal Federal em 19664', até a Constituição da República de 1988, com a previsão de indenização pelo dano moral, e de hipótese de responsabilidade independente de culpa, o país assistiu a uma efetiva mudança sobre o tema. Em 2002, o novo Código Civil manteve a direção do percurso: a responsabilidade civil foi tratada em Título próprio - "Da Responsabilidade Civil" -, em que se buscou melhor sistematizar a matéria, mas que não logrou, contudo, êxito em pacificá-la. Dentre os ruídos produzidos, especial rumor adveio das chamadas "reduções equitativas".

O primeiro destaque é dirigido à exceção prevista para o enunciado geral de arbitramento da indenização (art. 944, CC - "A indenização mede-se pela extensão do dano"), cujo preceito dispõe: "Se houver excessiva desproporção entre a gravidade da culpa e o dano, poderá o juiz reduzir, equitativamente, a indenização".

Uma outra hipótese é a do parágrafo único do art. 928, CC, o qual, no âmbito da responsabilidade subsidiária dos incapazes, estabelece que "a indenização prevista neste artigo, que

\footnotetext{
1 Para uma exposição sobre a questão, por todos, TEPEDINO, G. Premissas metodológicas para a constitucionalização do direito civil. Revista de Direito do Estado, v. 2, 2006, p. 37-53.

2 MORAES, M. C. B. Danos à pessoa humana: uma leitura civil-constitucional dos danos morais. 2. ed. Rio de Janeiro: Processo, 2017. p. 154.

${ }^{3} \mathrm{Em}$ recuperação precisa deste percurso: SCHREIBER, A. Novos paradigmas da responsabilidade civil: da erosão dos filtros de reparação à diluição dos danos. 6. ed. São Paulo: Atlas, 2015. p. 9-53.

${ }^{4}$ Cf. RE 59.940/SP, RTJ 39/38-44.
} 
deverá ser equitativa, não terá lugar se privar do necessário o incapaz ou as pessoas que dele dependem".

Estes dispositivos, embora estruturalmente diferentes quanto à sua aplicabilidade, apresentam um mesmo núcleo funcional: uma situação que, em detrimento da integral compensação, autoriza uma redução da indenização, em contramarcha ao caminhar da própria responsabilidade civil, voltada à reparação integral. O paradoxo legislativo foi - e ainda é - alvo de inúmeras produções doutrinárias ${ }^{5-6}$, as quais buscam harmonizá-lo aos valores do ordenamento, pautando a sua justificativa na salvaguarda de um patrimônio mínimo, de modo a não transferir a desgraça da vítima para o ofensor ${ }^{7}$.

Esta interpretação, contudo, traz para o momento de imputação e quantificação da indenização um elemento estranho à responsabilidade civil, qual seja, determinar quanto do patrimônio pessoal do ofensor poderá utilizar-se para o pagamento de determinados créditos. Assim, neste trabalho, pretende-se afastar um equívoco de tal envergadura com o delineamento das fronteiras de dois temas próximos, mas que não se mesclam: a responsabilidade civil e a responsabilidade patrimonial.

\section{UMA HISTÓRIA DE PARALELOS-PARADOXAIS: TRAJETÓRIA DA REDUÇÃO EQUITATIVA NO BRASIL}

A jurisprudência das últimas décadas, embora marcada por percalços que the são inerentes, percorreu uma direção no sentido de garantir, em matéria de responsabilidade civil, a cobertura de todo dano sofrido e todo o dano experimentado pelas vítimas ${ }^{8}$. A Constituição da República, neste

\footnotetext{
${ }^{5}$ Sob o viés civil-constitucional: SILVA, D. F.; BUSTAMANTE, T. Neminem Laedere: o novo Código Civil brasileiro e a integral reparabilidade dos danos decorrentes de ato ilícito. Revista Trimestral de Direito Civil, Rio de Janeiro, v. 20, out/dez, 2004. p. 247-258; KONDER, C. N. A redução equitativa da indenização em virtude do grau de culpa: apontamentos acerca do parágrafo único do art. 944 do Código Civil. Revista Trimestral de Direito Civil, Rio de Janeiro, v. 29, jan./mar., 2007. p. 3-34; MONTEIRO FILHO, C. E. R. Artigo 944 do Código Civil: o problema da mitigação do princípio da reparação integral. In: TEPEDINO, G.; FACHIN, L. E. (Org.). O direito e o tempo: embates jurídicos e utopias contemporâneas - estudos em homenagem ao professor Ricardo Pereira Lira. Rio de Janeiro: Renovar, 2008, v. 1. p. 757-796; BANDEIRA, P. G. Notas sobre o parágrafo único do artigo 944 do Código Civil. Civilistica.com. Rio de Janeiro, a. 1, n. 2, jul./dez. /2012. Sobre o art. 928, CC: FACCHINI NETO, E.; ANDRADE, F. S. de. Notas sobre a indenização equitativa por danos causados por incapazes: tendência ou excepcionalidade no sistema da responsabilidade civil no Direito brasileiro? Revista Brasileira de Direito Civil - RBDCivil, Belo Horizonte, v. 13, jul./set. 2017, p. 93-115.

${ }^{6}$ Para obras que tratam de questões mais gerais, embora abordem o assunto, ressalte-se: CALIXTO, M. J. A culpa na responsabilidade civil: estrutura e função. Rio de Janeiro: Renovar, 2008. p. 299-326; SANSEVERINO, P.T.V. Princípio da reparação integral. São Paulo: Saraiva, 2010. p. 80-134; GUEDES, G. S. C. O problema do nexo causal na responsabilidade civil. Rio de Janeiro: Renovar, 2005. p. 327-333.

${ }_{7}$ MONTEIRO, W. B. Curso de direito civil: direito das obrigações. Atualizado por MALUF, C. A. D.; SILVA, R. B. T da. 39. ed. São Paulo: Saraiva, 2012, v. 5. p. 935; TERRA, A. M. V.; GUEDES, G. S. C. Responsabilidade civil dos pais pelos atos praticados pelos filhos menores. Revista de Direito Civil Contemporâneo, São Paulo: Revista dos Tribunais, v. 17, n. 5, p. 135-154, out./dez., 2018. p. 152.

${ }^{8} \mathrm{O}$ que consistiria na reparação integral, conforme MONTEIRO FILHO, C. E. R. Limites ao princípio da reparação integral no direito brasileiro. Civilistica.com. Rio de Janeiro, a. 7, n. 1, 2018. p. 5-6.
} 
cenário, buscou tutelar não apenas a reparação, mas também a sua realização de forma integral (art. $1^{\circ}$, inciso III; art. 5은, inciso $\mathrm{V}, \mathrm{X}$ e XXII, CR) ${ }^{9}$.

Não obstante, parte da doutrina, embora assim também entendesse sob a égide do Código Civil de 1916, defendia que a indenização portava um caráter moralizador, medido na presença da culpa. Desta forma, quando aplicada a reparação irrestrita do dano de grandes proporções, mas originado por ato de baixa reprovabilidade do agente causador, seria possível haver uma iniquidade no sistema ${ }^{10}$.

Imbuído neste espírito, o Código Civil de $2002{ }^{11}$ trouxe exceção à reparação integral, a qual defendeu-se vigorosamente pelos que relacionavam a redução equitativa à completude e equilíbrio do sistema, em dois momentos estruturalmente diferentes.

\subsection{O ARTIGO 944, PARÁGRAFO ÚNICO: REPARAÇÃO INTEGRAL E PERPLEXIDADES}

A previsão de redução do quantum a ser indenizado, quando se verifica a desproporção entre a culpa do ofensor e o resultado danoso, é uma das provas de que, após quase trinta anos de tramitação, nascia velho o Código Civil de $2002^{12}$. Esta disposição legal, prevista no parágrafo único do art.944, CC, contextualiza-se na perspectiva da responsabilidade civil que ainda se baseava, predominantemente, na análise da existência de culpa para fins de determinar o dever de indenizar.

Em outras palavras, a exceção à regra expressa do caput do art. $944^{13}, \mathrm{CC}$, um dos pilares da responsabilidade civil, demonstra resquício moralizador, no sentido de imputar ao ofensor uma responsabilidade na medida de seus atos, em detrimento do direito a compensação da vítima. Diante, também, da cláusula geral de responsabilidade objetiva do art. 927, $\mathrm{CC}^{14}$, parece apenas se reforçar

\footnotetext{
${ }_{9}^{9}$ MONTEIRO FILHO, C. E. R. Limites ao princípio da reparação integral no direito brasileiro..., p. 2-3.

10 Registre-se, porém, que inexistia dispositivo legal neste sentido no Código Civil de 1.916. Diferente era a posição adotada em alguns países europeus, como a Suíça, onde subsiste expresso dispositivo no sentido de redução equitativa do quantum indenizatório, ou Portugal, onde a equidade qualifica-se como elemento para quantificar indenizações fundadas na culpa, fixados, como parâmetros de aplicação deste conceito aberto, o grau de culpa e a situação econômica das partes. A posição adotada pelo European Group of Tort Law, incumbido de delinear os princípios da responsabilidade civil que virão a integrar o Código Civil europeu, foi semelhante a existente neste último país. Sobre o assunto, confira-se: KONDER, C. N. A redução equitativa da indenização em virtude do grau de culpa..., p. 10-13.

11 Agostinho Alvim, incumbido do texto do Direito das Obrigações no Projeto de 1975, do qual Código Civil de 2002, após citar expressamente a legislação suíça afirmou, ainda sob a égide do Código Civil de 1916, que: "O juiz pode sentir-se inclinado a negar a culpa, para evitar uma condenação que não comporta meio-termo. É verdade que o juiz não deve fazer isso, mesmo porque a dureza é da lei e não dele. Mas o certo é que, se em casos tais ele não tiver algum arbítrio, não se evitarão os julgamentos por sentimentalismo, impropriamente ditos por equidade". (Da inexecução das obrigações e suas consequências. 5. ed. São Paulo: Saraiva, 1980. p. 201).

12 Seja permitido remeter a TEPEDINO, G. O Novo Código Civil: duro golpe na recente experiência constitucional brasileira. Revista Trimestral de Direito Civil (editorial), Rio de Janeiro, v. 7, a. 2, jul./set., 2001.

${ }^{13}$ Ressaltando esta característica, KONDER, C. N. A redução equitativa da indenização em virtude do grau de culpa..., p. 15; CAVALIERI FILHO, S. Programa de responsabilidade civil. 11. ed. São Paulo: Atlas, 2014, p. 200.

${ }^{14}$ Ressalte-se que predomina a posição de inaplicabilidade do art. 944, parágrafo único, CC à responsabilidade objetiva. Ora, se na responsabilidade objetiva instaurou-se um sistema de não discussão da culpa, política legislativa de impor ao ofensor suportar o dano, excetuando-se apenas a quebra do nexo causal, não é cabível o retorno a culpa no momento da quantificação. Neste sentido: ROSENVALD, N; FARIAS, C. C. de; BRAGA NETTO, F. P. Curso de direito civil: responsabilidade civil. 5. ed. Salvador: JusPodivm, 2018, v. 3. p. 498s; KONDER, C. N. A redução equitativa da indenização em virtude do grau de culpa..., p. 12; BANDEIRA, P. G. Notas sobre o parágrafo único do artigo 944 do Código Civil..., p. 20; SANSEVERINO, P. T. V. Princípio da
} 
o deslocamento do dispositivo em sentido oposto à reparação integral e a prevalência da tutela da vítima no sistema de responsabilidade civil brasileiro ${ }^{15}$.

Sob esta perspectiva, visualiza-se um movimento doutrinário tendente a consolidar a redução equitativa em fundamentos que justifiquem esta oposição. Assim, afirmou-se como amparo da normativa a equidade humanitária, para que a indenização não reduzisse o ofensor a situação patrimonial impeditiva de sua sobrevivência.

Com efeito, dividem-se as opiniões sobre a ferramenta adequada para evitar-se este efeito repudiado. De um lado, afirma-se ser necessário um controle, no momento da quantificação do valor de indenização, da disparidade de condição financeira abstrata das partes, pouco importando a possibilidade ou impossibilidade de o ofensor pagar a indenização ao ofendido ${ }^{16}$; de outro, parte da doutrina encontra o fundamento da norma na solidariedade constitucional (art.3o, inciso I CF), obstando o arbitramento integral de indenização em detrimento ao patrimônio de subsistência do ofensor. Portanto, e em razão dos relevantes motivos do ordenamento jurídico que amparam as referidas normas, haveria um contrabalanceamento, buscando evitar a anulação dos direitos do ofensor pela garantia dos direitos do lesado ${ }^{17}$. Assim, recorrem-se as razões constitucionais que justificam a redução equitativa, para the emprestar força equiparável à reparação integral.

Chegam alguns autores a sugerir o uso do método da ponderação de princípios constitucionais sempre que se pretenda aplicar o dispositivo, balanceada a reparação integral com

reparação integral..., p. 106. Minoritária a opinião no sentido de que a quantificação é momento também presente na responsabilidade objetiva e nele deve ser retomado o art. 944, parágrafo único. Destaca-se aqui: MONTEIRO FILHO, C. E. R. Limites ao princípio da reparação integral no direito brasileiro..., p. 21s. Ressalte-se que esta posição, embora minoritária na doutrina, ganha força com a reforma do enunciado 46 da I Jornada de Direito Civil ("A possibilidade de redução do montante da indenização em face do grau de culpa do agente, estabelecida no parágrafo único do art. 944 do novo Código Civil, deve ser interpretada restritivamente, por representar uma exceção ao princípio da reparação integral do dano[,] não se aplicando às hipóteses de responsabilidade objetiva") pelo enunciado 380 da IV Jornada de Direito Civil ("Atribui-se nova redação ao Enunciado n. 46 da I Jornada de Direito Civil, pela supressão da parte final: não se aplicando às hipóteses de responsabilidade objetiva").

${ }^{15}$ A própria jurisprudência do Superior Tribunal de Justiça poucas vezes utilizou o dispositivo ao fundamentar a quantificação de danos. O caso mais recente pesquisado (STJ, REsp 1724719/SP, 3a Turma, Rel. p/ acórdão Min. Ricardo Villas Bôas Cueva, j. 15/05/2018) o aplicou para reduzir indenização devida por empresa à instituição financeira, pela emissão fraudulenta de cédulas de crédito rural. O julgado afirmou ser o dano, entrada da vítima em processo de falência, não decorrente apenas das atitudes do ofensor. No caso concreto parece haver alguma imprecisão técnica entre a análise da culpa e do nexo causal. Afinal, não seria possível afirmar ser uma determinada "culpa", ilicitude, causadora de dano, mas sim que as fraudes operadas não foram a causa, ou não única, por subsistirem outras concorrentes, do dano insolvência, sistemática que poderia influir, severamente, no resultado do processo (desde repartição dos prejuízos proporcionalmente entre todos que 0 causaram, até a não indenização, quando não se verificar o nexo).

${ }^{16}$ GONÇALVES, C. R. Direito civil brasileiro: responsabilidade civil. 4. ed. São Paulo: Saraiva, 2009, v. 4, p. 405; MONTEIRO, W.B. Curso de direito civil: direito das obrigações..., v. 5, p. 935. A opinião recebe críticas de quem enxerga nela um indevido empréstimo de legislações como a portuguesa, que adotaram o critério anteriormente suscitado, expressamente, para definir os parâmetros de redução equitativa por desproporção entre culpa e dano, critérios que não existem no direito brasileiro, apenas subsistindo a cláusula aberta em si (KONDER, C. N. A redução equitativa da indenização em virtude do grau de culpa..., p. 22).

17 BANDEIRA, P. G. Notas sobre o parágrafo único do artigo 944 do Código Civil..., p. 14s; MONTEIRO FILHO, C. E. R. Limites ao princípio da reparação integral no direito brasileiro..., p. 12; TEPEDINO, G. MORAES, M. C. B.; BARBOZA, H. H. et al. Código Civil interpretado conforme a Constituição da República. Rio de Janeiro: Renovar, 2012, v. III, p. 823s; KONDER, C. N. A redução equitativa da indenização em virtude do grau de culpa..., p. 33; SANSEVERINO, P. T. V. Princípio da reparação integral..., p. 134s; ROSENVALD, N; FARIAS, C. C. de; BRAGA NETTO, F. P. Curso de direito civil: responsabilidade civil..., v. 3. p. 207; CAVALIERI FILHO. Programa de responsabilidade civil..., p. 54. Ressalte-se que Marcelo Junqueira Calixto afirma ser esta a única interpretação possível de não eivar o dispositivo da inconstitucionalidade (CALIXTO, M. J. A culpa na responsabilidade civil: estrutura e função..., p. 323). 
outro princípio, principalmente, o do respeito ao mínimo existencial, para demonstrar a possibilidade de redução equitativa ${ }^{18}$. Embora seja reconhecido o louvável esforço de conciliação entre a escolha legislativa e a tabua axiológica do ordenamento jurídico, a solução guiada pelo mínimo existencial parece não atentar à matéria específica apta a proteger o patrimônio do devedor. Trata-se da responsabilidade patrimonial, a qual não pode absolver-se pela responsabilidade civil, sob pena de desrespeito a uma sistemática específica prevista no ordenamento jurídico.

\subsection{O ART. 928: RESPONSABILIZAÇÃO CIVIL, MITIGADA, DOS INCAPAZES}

Quanto ao art. 928, CC, diz-se que apresentou evolução no sentido de reparação ao lesado. Isto porque, conforme uma determinada concepção, admitiu-se recair a responsabilidade sobre o ofensor considerado inimputável, pela inaptidão para quaisquer dos atos da vida civil ${ }^{19}$.

As demais considerações sobre o caput do artigo, o qual traz a referida inovação, não são de maior relevância para o estudo pretendido. Quanto ao parágrafo único, mais próximo do tema ora tratado, assemelha-se, em seu perfil funcional, ao dispositivo que se observou no tópico acima. Dito de outra forma, por razão de equidade, permite-se a redução da indenização devida pelo incapaz.

Nestes termos, modifica-se apenas o motivo para tanto, qual seja, o fato desta privar o incapaz, ou as pessoas que dele dependem, do necessário para subsistência. Diante deste contexto, prevê também a supracitada regra não só a redução, mas sim a possibilidade de (suposta) inexistência do dever de indenizar diante da situação verificada no caso concreto20.

Novamente, posiciona-se a doutrina no sentido de proteção ao mínimo de subsistência, desta vez daquela pessoa incapaz ${ }^{21}$. Também para este dispositivo, o despertar da responsabilidade patrimonial é imprescindível, por sua adequação e potencialidade, no sentido de interpretá-lo de forma coerente ao ordenamento jurídico.

\section{DOS DESCAMINHOS NA BUSCA DE UM PONTO DE ENCONTRO: DA "REDUÇÃO EQUITATIVA HUMANITÁRIA" À RESPONSABILIDADE PATRIMONIAL}

Em análise das interpretações propostas para as cláusulas de redução equitativa pode se afirmar que o caminho sugerido pela doutrina atribui à responsabilidade civil uma incumbência

\footnotetext{
${ }^{18}$ KONDER, C. N. A redução equitativa da indenização em virtude do grau de culpa..., p. 32; BANDEIRA, P. G. Notas sobre o parágrafo único do artigo 944 do Código Civil..., p. 14s.; MONTEIRO FILHO, C. E. R Limites ao princípio da reparação integral no direito brasileiro..., p. 4s. Ressalte-se ainda a posição intermediária de Paulo de Tarso Sanseverino, classificando a norma como postulado normativo, conforme a teoria dos princípios de Humberto Ávila, o que resulta na essencialidade, de cunho constitucional, da consideração de existência digna na análise de possibilidade de reparação por danos e quantificação. SANSEVERINO, P. T. V. Princípio da reparação integral..., p. 119s.

${ }^{19}$ FACCHINI NETO, E., ANDRADE, F. S. de. Notas sobre a indenização equitativa por danos causados por incapazes... p. 98; MULHOLLAND, C. A responsabilidade civil da pessoa com deficiência psíquica e/ou intelectual. In: MENEZES, J. B. de (Org.). Direito das pessoas com deficiência psíquica e intelectual nas relações privadas. Rio de Janeiro: Processo, 2016, p. 642.

${ }_{20}$ SANSEVERINO, P. T. V. Princípio da reparação integral..., p. 130s.; FACCHINI NETO, E., ANDRADE, F. S. de. Notas sobre a indenização equitativa por danos causados por incapazes..., p. 107.

${ }^{21}$ SANSEVERINO, P. T. V. Princípio da Reparação Integral..., p. 130 e 134; FACCHINI NETO, E., ANDRADE, F. S. de. Notas sobre a indenização equitativa por danos causados por incapazes..., p. 107s; MONTEIRO FILHO, C. E. R. Artigo 944 do Código Civil..., p. 772.
} 
estranha a ela. Neste sentido, ressalte-se a própria estrutura de fixação do dever de indenizar do ofensor. Primeiramente, analisa-se a existência da responsabilidade civil através de seus pressupostos, o chamando an debeatur e, após, o arbitramento do dano sofrido a partir da quantificação, quantum debeatur22.

Sob o aspecto da quantificação do dano, é imprescindível o respeito ao caput do art. 944, CC. A eventual aplicação das normas de redução equitativa não pode se fixar nesta ocasião, pois é completamente estranha à sua estrutura e função.

Apenas posteriormente, após a constituição do crédito $^{23}$, com vistas à sua satisfação integral, é que, mediante a análise de todas as relações econômicas do ofensor (o seu patrimônio art. 91, CC), decidir-se-á se o valor integralmente fixado será pago, ou não.

Nesta perspectiva, a proibição de que o patrimônio dignitário do devedor seja completamente excutido por suas dívidas não tem a ver com o aspecto quantitativo da condenação de indenizar alguém, mas sim com a possibilidade de saldar este crédito. É por esta razão que o tema deve tratar-se na seara da responsabilidade patrimonial ${ }^{24}$.

\subsection{RESPONSABILIDADE PATRIMONIAL NO DIREITO BRASILEIRO: ENTRE O RESGATE E A NECESSÁRIA SISTEMATIZAÇÃO DOGMÁTICA}

O confronto do débito da pessoa com o seu patrimônio traduz, sempre, uma verdadeira situação jurídica coletiva ${ }^{25}$. Nesta perspectiva, analisa-se quais bens respondem pelo adimplemento de débitos, compondo assim o chamado acervo responsável, e quais outros não são passíveis de

22 MONTEIRO FILHO, C. E. R. Limites ao princípio da reparação integral no direito brasileiro..., p. 6.

23 Interessante notar obras de "direito das obrigações" escritas durante a vigência do Código Civil de 1916, as quais não tratavam de forma específica, em livro apartado, a responsabilidade civil, ou, quando o faziam, não dedicavam um volume tão grande de páginas ao assunto. Esta lógica unitária do direito obrigacional traz uma sábia lição para separação dos "planos" em que se trata a responsabilidade civil e a responsabilidade patrimonial. Afinal, após a sentença, ou acórdão, a qual fixa a indenização, forma-se um crédito, constituído por via judicial, e, consequentemente, aplicam-se a ele todas às regras, materiais e processuais, referentes ao adimplemento das obrigações, posto que subsiste a indenização como objeto da prestação indenizar (GOMES, O. Responsabilidade civil. Atualizado por E.B. Rio de Janeiro: Forense, 2011. p. 45 e 50).

24 BUCAR, D. Função do patrimônio e reabilitação negocial do insolvente: superendividamento da pessoa humana e outros instrumentos. 2016. Tese (Doutorado em Direito). Faculdade de Direito da Universidade do Estado do Rio de Janeiro, Rio de Janeiro, p. 50. Sublinhe-se um dado importante, o qual verifica-se na legislação portuguesa, qual seja, o não tratamento originário da insolvência, como impossibilidade patrimonial de satisfação das obrigações pelo devedor, no Código Civil de Portugal. Portanto, quando esta lei entra em vigência naquele ordenamento jurídico (1966), e prevê a possibilidade de redução equitativa no momento da quantificação do dano, nos casos em que a situação econômica do ofensor a justifique, inexistia previsão legal referente aos patrimônios em que o passivo superava o ativo. Naquele país, a alteração ocorreu apenas em 2004, e por meio de legislação esparsa, o chamado "Código de Insolvência e Recuperação de Empresas". Com efeito, até mesmo o contexto normativo brasileiro diferencia-se, pois, ao que pesem as críticas, o Código de Processo Civil de 1.973, já tratava no Livro II, Título IV, as chamadas "execuções contra devedor insolvente", tema inclusive da tese de cátedra do autor originário daquele projeto legislativo, Alfredo Buzaid (para uma perspectiva crítica da sistemática brasileira de insolvência, remete-se a BUCAR, D. Função do patrimônio e reabilitação negocial do insolvente..., p. 97-120). Ou seja, quando as reduções equitativas aportaram na legislação brasileira já se conhecia não só a insolvência civil de pessoas físicas, como também aquela de pessoas jurídicas por meio da antiga Lei de Falências e Concordatas (Decreto-Lei no 7.661/45).

25 Sobre o assunto, BUCAR, D. Superendividamento: por um tratamento coletivo de débitos. In: TEPEDINO, G.; MENEZES, J. B. de (Coord.). Autonomia privada, liberdade existencial e direitos fundamentais. Belo Horizonte: Fórum, 2019. p. 710s. 
execução, integrantes de seu patrimônio de dignidade. Desta análise inicial é possível delimitar qual o ativo existente, para que o devedor responda por suas obrigações.

Quando se verifica que os débitos são maiores que os créditos, será aberto o concurso de credores. Observam-se aqui as preferências creditórias e, dentro de uma mesma classe de credores, a divisão igualitária dos valores que compõe o acervo responsável.

Mais adequado, portanto, pensar o pagamento do crédito nesta visualização complexa do patrimônio, colocando-o frente ao conjunto de normas que a ele se dedicam. Caso se aceite que, no momento da quantificação do dano, reduza-se a indenização com vistas ao resguardo do patrimônio de subsistência do ofensor haverá, senão uma redundância (pois as obrigações já se extinguem por inexistência de patrimônio ${ }^{26}$ ), uma inegável submissão da capacidade das partes à extensão de seu patrimônio. Em outras palavras, é dizer que uma pessoa é mais ou menos civilmente responsável e, por conseguinte, mais ou menos dotado de capacidade civil, por conta da expressão de seu patrimônio. Pessoas, contudo, não se medem por seu patrimônio.

Por outro lado, na execução do crédito, fixado na exata extensão do dano, a eventual impossibilidade de subtrair do executado o seu patrimônio de dignidade, para fins de responsabilidade patrimonial, será contemplada, impedindo assim que seus débitos o façam miserável27.

Para além desta confusão técnica, o fundamento que se pretende destinar às reduções equitativas no direito brasileiro representa quebra sistemática no atual ordenamento jurídico, vez que é nota característica deste um sistema concursal, o qual engloba, irrestritamente, todas as dívidas ${ }^{28}$. Com efeito, é imprescindível observarem-se as complexas escolhas legislativas, presentes nos arts. 961 a $965, C^{29}$ e art. 83 da Lei 11.101/05, as quais determinam quem recebe primeiro.

O caminho da redução equitativa, portanto, sugere via temerária, que gera subversão a esta hermenêutica. Cuida-se da fixação de indenização, em um processo individual, nos limites de esvaziamento do acervo responsável, com base nos arts. 944, parágrafo único ou art. 928, parágrafo único, CC.

Conforme esta hipótese, acaso haja adimplemento espontâneo do devedor ou bemsucedida execução pelo rito aplicável aos devedores solventes, dentro do processo de responsabilização, ignora-se a possibilidade de que a visão coletiva daquele patrimônio demonstrasse situação de insolvência, ou de que o pagamento da indenização reduzida ocasione a impossibilidade de pagamento de outros débitos.

\footnotetext{
${ }^{26}$ Como autoriza, em processos coletivos próprios, o art. 778, CPC/73 (em vigor, conforme art. 1.052, CPC/15) e o art. 158, III e IV, da Lei 11.101/15 (Lei de Recuperação Judicial e Falência).

${ }^{27}$ BUCAR, D. Função do patrimônio e reabilitação negocial do insolvente..., p. 71. Registre-se sintomática afirmação de alguns autores, no sentido de que, concretizar a redução equitativa é levar em conta, no momento de quantificar a indenização da pessoa incapaz, existência de um único bem de família presente no seu patrimônio, protegido na forma da Lei 8.009/90 (FACCHINI NETO, E.; ANDRADE, F. S. de. Notas sobre a indenização equitativa por danos causados por incapazes..., p. 108. Contudo, o próprio artigo $1^{\circ}$ desta lei ordena proteção a título de impenhorabilidade, ou seja, momento de excussão para satisfação do débito, sem qualquer previsão de relevância deste fato na constituição do mesmo.

${ }^{28}$ BUCAR, D. Superendividamento: por um tratamento coletivo de débitos..., p. 711

${ }^{29}$ Para uma releitura deste rol de preferências, BUCAR, D. Função do patrimônio e reabilitação negocial do insolvente..., p. 81-94.
} 
Diante deste cenário, de falta de ativo para o pagamento de todo o passivo em favor de um crédito individual, desconsidera-se o pagamento de outros, eventualmente preferenciais, ou a igual divisão de valores entre demais credores que estejam na mesma posição concursal que o lesado. Dito de outra forma, privilegia-se o vínculo quando o ordenamento jurídico considerou merecedora de tutela solução mais ampla e solidária.

Este modo de proceder e também aquele que adapta, de forma abstrata, o valor da indenização à comodidade de pagamento de todos os créditos do ofensor, poderá, inclusive, prejudicar ao lesado. Afinal, segundo as preferências no estado de insolvência, este pode ser o principal credor a receber.

Enfim, conclui-se, por meio da sistemática ora apresentada, que ao eleger-se a responsabilidade civil, por meio de redução equitativa, como disciplina que corretamente analisa a proteção do patrimônio do devedor, repita-se, comete-se grave equívoco. Todas as regras e fundamentos próprios de um sistema existente de responsabilidade patrimonial correm o risco, constante, de desconsideração.

Não apenas, mas também se afasta, tanto o devedor, quanto os seus credores, da sua correta proteção, a qual somente se legitima pelo sistema de responsabilidade patrimonial delineado pelo próprio ordenamento jurídico.

\subsection{INSTRUMENTOS DE PROTEÇÃO, E REABILITAÇÃO PATRIMONIAL, DO OFENSOR SUPERENDIVIDADO NA UNIDADE DO ORDENAMENTO}

Ao apontar-se a inconsistência da construção interpretativa cujo intento era harmonizar a redução equitativa ao direito brasileiro, e lhe conceder função de importância equivalente à reparação integral, não se nega proteção ao patrimônio do ofensor, tampouco se almeja condená-lo a situação de impossibilidade do pagamento de débitos, como espécie de punição. Pelo contrário, apenas se opõe a tendência de inchaço nas funções da responsabilidade civil, neste caso atribuída ao momento de arbitramento do dano, quando o instituto deveria conter-se na difícil tarefa de reparação do dano injusto ${ }^{30}$.

Conforme tal perspectiva, pelo estudo de algumas situações hipotéticas, visualiza-se não só a adequação de análise do patrimônio do ofensor a partir da responsabilidade patrimonial, como sua coerência a dogmática do ordenamento jurídico brasileiro. Ainda, demonstra-se que o expediente não traz qualquer ofensa a diretriz constitucional de proteção da pessoa humana.

Tome-se o exemplo didático, sugerido por Silvio Rodrigues, do pedreiro que vai ao trabalho de bicicleta e, no percurso, por pequena falta de cautela, acaba por causar um acidente, colidindo com um veículo luxuoso ${ }^{31}$. Aqui, mostra-se completamente inadequado o juiz, de ofício, mediante análise da profissão do lesante e do seu meio de transporte, reduzir a indenização a ser paga,

30 Para obra paradigmática neste sentido, de delimitar a dogmática da responsabilidade civil dentro dos esquadros de suas funções no ordenamento jurídico brasileiro, SCHREIBER, A. Novos paradigmas da responsabilidade civil..., passim.

${ }^{31}$ RODRIGUES, S. Direito civil: responsabilidade civil. 19. ed. São Paulo: Saraiva, 2002, v. 4. p. 206. 
constituindo débito a menor do que o dano sofrido. Nem mesmo cogita-se de o ofensor alegar em contestação, seja de forma abstrata ou por prova concreta, de inexistência de bens penhoráveis ${ }^{32}$, impossibilidade de pagamento do débito a título de responsabilidade civil.

A perplexidade pragmática que estes procedimentos despertam diz respeito à equivocada antecipação do debate acerca da possibilidade de pagamento antes da própria sentença condenatória. Como já foi dito anteriormente, é no momento processual da execução do débito que se analisa-se quais bens poderão, ou não, satisfazer a obrigação.

Assim, haverá o momento adequado para proteger o ofensor, que se torna, somente após a sentença, devedor de um título judicial. Suponha-se que o mesmo pedreiro seja um trabalhador que recebe salário que se dilui mês a mês, destinado ao custeio de despesas ordinárias para sua sobrevivência. No rol dos seus direitos reais de propriedade encontram-se apenas ferramentas de trabalho e um único imóvel onde habita. Mesmo que o dano material integral apurado seja de alto valor, o credor-vítima do acidente não receberá a indenização por falta de acervo responsável.

A própria legislação brasileira protege o patrimônio de dignidade de devedores nestas condições, consoante o disposto no art.1 ${ }^{\circ}$ da Lei 8.009/90 (Lei do Bem de Família) e, também, art. 833, inciso IV e V, CPC, sem que seja necessária qualquer redução equitativa para proteção daquele ofensor.

Tal situação deverá ser resolvida no âmbito de um processo coletivo (execução contra devedor insolvente - artigos 748 e seguintes do Código de Processo Civil de 1973), em que se verificará a preferência dos créditos de acordo com a axiologia do ordenamento (por ora, tem-se a infeliz classificação dos artigos 957 a 965 do Código Civil) para pagamento possível e, caso haja inviabilidade de liquidar algum saldo, extinguir-se-á as obrigações não pagas, na forma prevista no art. 778 do $\mathrm{CPC} / 73$.

\section{REDUÇÃO EQUITATIVA: PERSPECTIVAS DE INTERPRETAÇÃO NA LEGALIDADE CONSTITUCIONAL}

Ainda que se entenda a proposta de harmonizar a redução equitativa à axiologia constitucional, não se pode fazê-lo por meio de uma artificial conexão à proteção do mínimo existencial, alcançada por meios efetivos, seguros e coletivos em nosso ordenamento. No entanto, comunga-se dos pressupostos que originaram estes esforços interpretativos, empenhados em não esvaziar a importância constitucional atribuída à reparação integral, mas, ao mesmo tempo, não se esquivar ao cumprimento da lei.

Com efeito, a proposta de uma cláusula geral de redução equitativa advém de outro momento, o qual caracterizava-se por uma normativa da responsabilidade civil cuja prioridade era distinta. A perplexidade, a que esta norma se propôs a resolver, se iniciava no fato do ofensor

\footnotetext{
${ }^{32} \mathrm{Na}$ defesa deste procedimento como possível, veja-se SANSEVERINO, P. T. V. Princípio da reparação
} integral..., p. 133. 
responder por danos muito maiores do que aqueles que sua vontade poderia compreender no momento em que praticou o ato ilícito.

No cenário atual tais voluntarismos não mais encontram lugar. Por tais razões, não se olvida ser a tarefa de compatibilização, tanto do art. 944, quanto do art. 928, CC, ao atual ordenamento, um grande desafio.

É por esta razão que, para além dos debates sobre os atuais esforços neste sentido, se pretendem lançar algumas proposições de nova hermenêutica para estes dispositivos. Registre-se que não se pretendem encerrar as discussões sobre o assunto, e sim prestar-se um pequeno contributo.

\subsection{RESPONSABILIDADE (PATRIMONIAL) DOS INCAPAZES}

O art. 928, sob a análise das perspectivas aqui apresentadas, não se trata, pelo menos em parte, de norma de responsabilidade civil, mas sim de uma das regras de responsabilidade patrimonial, as quais, repita-se, não foram sistematizadas no direito brasileiro. Veja-se sua literalidade: "o incapaz responde pelos prejuízos que causar, se as pessoas por ele responsáveis não tiverem obrigação de fazê-lo ou não dispuserem de meios suficientes". Continua, por meio da ressalva do parágrafo único: "a indenização prevista neste artigo, que deverá ser equitativa, não terá lugar se privar do necessário o incapaz ou as pessoas que dele dependem".

Ao afirmar-se que o incapaz responde pelos prejuízos que causar quando os pais não dispuserem de meios suficientes, não se está apresentando nenhum comando ao julgador na avaliação e quantificação do dano. Em verdade, versa a questão sobre a impossibilidade do pagamento, pelos pais, de crédito consolidado e autorização, de forma subsidiária, da excussão do patrimônio do filho, causador do dano, o qual estabeleceu-se anteriormente, na fase de conhecimento do processo.

Permite-se assim, tão só, a utilização do patrimônio do menor, que esteja disponível como meio de garantir a indenização à vítima. Sublinhe-se que a incapacidade é indiferente para fins de responsabilidade patrimonial.

Toda pessoa humana, por carregar personalidade jurídica, apresenta aptidão para aquisição de direitos, no caso concreto titularidade de bens pelo menor, e obrigações, dever de entregá-los quando a lei assim ordenar. Nem mesmo subsiste qualquer exercício de direito, posto que a execução se faz por força da atividade do Estado-juiz, ressalvando-se apenas a necessária representação do menor em todos atos processuais.

Reforçar tal hermenêutica encontra-se não só em harmonia às mudanças na responsabilidade civil, mas sim do ordenamento total. Afinal, são também os pais do menor usufrutuários legais e administradores dos bens deste (art.1.689, incisos I e II, CC). Razoável admitir que, diante do ilícito praticado, os pais possam alienar bens do filho, ofensor, para o pagamento voluntário da obrigação, até mesmo como ensinamento de norma do convívio social, qual seja, a necessária reparação do prejuízo que se causou. 
Do mesmo modo, parece razoável a interferência judicial, quando não houver tal atitude, para que esta excussão ocorra, até mesmo por ser função de toda sociedade, e do Estado, a educação e inserção da criança e adolescente (art. 227, CR). Faz-se então o que poderia, e deveria, fazer o usufrutuário legal na falta de patrimônio próprio.

A norma que mitiga esta tentativa de efetivar o dever indenizatório, presente no parágrafo único, prevê o uso da equidade ao fazer com que o menor responda patrimonialmente, evitando-se a privação, deste e de sua família, do necessário para viver. Não se pode aqui ceder às noções mais costumeiras de juízo equitativo, no sentido de recorrer ao valor justiça externo ao direito, atuando a cláusula como meio de reequilíbrio do sistema por falta de normativa que desempenhe esta função ${ }^{33}$.

Tendo em vista toda a estrutura da responsabilidade patrimonial, suficiente para proteção do patrimônio de dignidade do menor, a norma significa, ao máximo, uma advertência de que o juiz não deve concretizar apenas o anseio de reparar os danos. Mesmo que em sede de execução, também é mandatório, ao julgador, concretizar a proteção do devedor-ofensor, sustentando o sistema de direito brasileiro, sem qualquer recurso externo, a harmonização dos interesses pretendida pelo art. 928, parágrafo único.

\subsection{REDUÇÃO EQUITATIVA POR DESPROPORÇÃO ENTRE GRAVIDADE DO DANO E CULPA: DA MITIGAÇÃO AO REFORÇO DA REPARAÇÃO}

O contexto que ora foi apresentado põe à prova a legitimidade e, de certa forma, a constitucionalidade do art. 944, parágrafo único. Primeiramente, a inegável força constitucional do princípio da reparação integral não permite sua simples mitigação por norma infraconstitucional, que não se justifique em valores da mesma importância. Ademais, a norma pensou-se no contexto de sua produção e, agora, encontra-se vigente em tempo completamente distinto.

Outra impossibilidade é alinhar o dispositivo aos ditames da responsabilidade patrimonial, pois a estrutura não é identificável à função desta disciplina. No momento de excussão do devedor discute-se existência de patrimônio e possibilidade de utilizá-lo para solver créditos. A pequena culpa na responsabilidade civil é exógena ao instituto, e não representa causa de menor expropriação patrimonial.

Por tal razão, esboça-se aqui uma sugestão de mudança interpretativa radical. Assim, ao revés de justificar a norma como exceção, sustentável seria considerá-la um reforço à reparação, regra de julgamento destinada ao juiz nos casos jurídicos de difícil aferição da culpa, e consequente surgimento da dúvida quanto ao dever de indenizar.

Embora insista-se na defesa da reparação integral, esta se faz em obediência ao mesmo ordenamento jurídico que optou pela manutenção da responsabilidade subjetiva. O que se renova é sua forma de análise. Assim, passa-se a verificar o standard socialmente adequado do agir no caso concreto, sua conformidade aos ditames do direito, fragmentando-se a culpa em "diversas culpas".

${ }^{33}$ SANSEVERINO, P. T. V. Princípio da reparação integral..., p. 90. 
Tratam-se de padrões diferentes, para se impor aos distintos grupos de pessoas, e não da procura psicológica de intenção do agente que ocorria outrora ${ }^{34}$.

Todavia, esta atividade, aparentemente simples, poderá, em alguns momentos, desafiar o intérprete. Por outras palavras, embora se visualize o dano com clareza, torna-se difícil dizer se o comportamento do ofensor é culposo. E o próprio ordenamento jurídico brasileiro determina a importância deste pronunciamento ao reafirmar o requisito ${ }^{35}$.

Para estes casos, em que a culpa se põe à prova, o dispositivo ora em comento demonstra grande potencialidade funcional, ao aplicar-se a solução em dois níveis. Quanto ao an debeatur, na dúvida, a regra de julgamento será em favor da responsabilização. No referente ao quantum debeatur esta falta de certeza sobre um dos pressupostos da responsabilidade civil seria razão de arbitramento da indenização em valor menor do que aquele equivalente a reparação integral.

Desta forma, evita-se que a dúvida se opere contra o lesado, hermenêutica contrária as atuais bases da responsabilidade civil, mas, ao mesmo tempo, não se permite fixar a indenização de forma contrária à dogmática da matéria. Assegura-se a coerência do ordenamento e resguardam-se os interesses do lesante e do lesado, na medida por aquele imposta.

Na verdade, trata-se de sútil presunção, uma ficção jurídica possível de auxiliar o julgador posicionando a pessoa diante do direito material ${ }^{36}$. Destaque-se que o itinerário apenas se aproveita na análise de culpa, sob pena de permitir utilização indevida do art. 944, parágrafo único, atraindo riscos ao ofensor em desconformidade as previsões do sistema atual. Tal debate é muito mais profundo e não pode se resolver de forma casuística, pois nomeia quem deve responder a determinados danos e por quais razões ${ }^{37}$.

A proposta interpretativa que se sugere é de grande utilidade para o exercício de funções do Judiciário na contemporaneidade. Por esta perspectiva, dispensa-se que o julgador lance mão de critérios mais abertos, como "as máximas da experiência". Em sentido oposto, invoca-se o parágrafo

\footnotetext{
${ }^{34}$ MULHOLLAND, C. A responsabilidade civil da pessoa com deficiência psíquica e/ou intelectual..., p. 646; SCHREIBER, A. Novos paradigmas da responsabilidade civil..., p. 42s, 45-47.

${ }^{35}$ Caso contrário, nem o Código Civil haveria disposto sobre culpa, tampouco haveria exceção ao regime geral de responsabilidade objetiva no Código de Defesa do Consumidor, ao dispor expressamente sobre a responsabilidade subjetiva dos profissionais liberais (art.14, $\left.\S 4^{\circ}\right)$. Entendendo desta forma, SOUZA, E. N. Do erro à culpa na responsabilidade civil do médico. Civilistica.com, Rio de Janeiro, a.2, n. 2, p. 1-27, 2013. p. 23s.

${ }^{36}$ MARINONI, L. G. Prova. São Paulo: Revista dos Tribunais, 2009, p. 138. Elegendo extenso rol de momentos onde o Código Civil utiliza-se deste expediente: DIDIER JÚNIOR, F. Curso de direito processual civil: da prova, direito probatório, decisão, precedente, coisa julgada e tutela provisória. 13. ed. Salvador: JusPodivm, 2018, p. $69 \mathrm{~s}$.

${ }^{37}$ São sedes adequadas a fixar estes parâmetros a adoção unitária de uma teoria para o nexo causal e os debates sobre política legislativa, tendo em vista, inclusive, a proliferação de novos danos na sociedade de risco. Faça-se ressalva ainda ao fato de que permitir a interpretação ora sugerida ao parágrafo único do art.944, CC, de forma extensiva aos outros pressupostos, é completamente distinto de afirmar que o art.945, CC, diz respeito não a culpa, mas as causas concorrentes para o dano. Neste último caso inexiste dúvida sobre o fato de que o ofensor causou o dano. Porém, admitir que na imprecisão sobre a causa do dano responde o ofensor significa dizer que a causa que não se verifica nitidamente ligada ao dano gera o dever de indenizar, o que se coincide com o afastamento das principais teorias sobre o nexo causal aceitas no Brasil, quais sejam, a da causalidade direta e imediata e a da causalidade necessária (quanto ao tema, TEPEDINO, G. Notas sobre o nexo de causalidade. In: TEPEDINO, G. Temas de direito civil. Rio de Janeiro: Renovar, 2006, t. II, p. 63/81). Neste momento, não se confirma ruptura desta profundidade, a qual merece maiores cautelas e eventuais desenvolvimentos em sede apartada. No entanto, imprescindível pontuar opinião em sentido contrário, ou seja, ampliando a redução equitativa não só no caso de culpa desproporcional ao dano, mas também de "causa distante" (SANSEVERINO, P. T. S. Princípio da reparação integral..., p. 123).
} 
único do art. 944, CC cumprindo-se o dever de argumentação na forma mais adequada (previsto constitucionalmente no art. 93, inciso IX, CF e, na lei processual, no art. 489, inciso II e $\S 1^{\circ}$, CPC), ao embasar-se em norma existente no sistema.

Desta forma, o dispositivo transporta-se, de sua antiquada posição, para o lugar de importante ferramenta cuja maior utilidade reside em auxiliar avaliação de novas situações, presentes no horizonte próximo da responsabilidade civil.

É o caso da pessoa com deficiência. Após sua retirada do rol dos incapazes, indaga-se como proceder diante da prática do ato ilícito sem que haja falta do discernimento, o que poderia prejudicar a imputabilidade ${ }^{38}$. Temerário responder a desafiadora questão segundo o binômio "subsistindo capacidade há responsabilidade - na existência de incapacidade responde-se apenas pela responsabilidade patrimonial subsidiária (art. 928 e seu parágrafo único, CC).

Ao perseguir-se a axiologia do Estatuto da Pessoa com Deficiência observa-se que seu principal objetivo é a promoção de autonomia e igual participação destes sujeitos na sociedade ${ }^{39}$. Ora, se este é o propósito a se alcançar por meio desta lei, sinaliza-se não ser completa a inclusão na realidade atual. Sob este aspecto imputar aos destinatários do Estatuto os mesmos deveres de conduta esperados dos cidadãos plenamente integrados a sociedade reflete-se em decisão que implica desigualdade material, além de desobediência às propostas da Lei Brasileira de Inclusão ${ }^{40}$.

Nesta perspectiva, algumas situações cotidianas podem ser percebidas de forma diferente, sem que deixem de ser entendidas, como acontece na falta de discernimento. Seria o caso de alguma reação desproporcional ao momento de adversidade na rotina de trabalho.

Assim, a culpa na responsabilidade subjetiva, nestes casos, passa a não ser de fácil análise, pois o padrão de conduta esperado das Pessoas com Deficiência, segundo as normas do direito brasileiro, não poderá confrontar aos princípios e valores do Estatuto. Nestes termos, situação relevante do lesado pondera-se ao interesse de reparação integral do ofendido e a atuação do art. 944, parágrafo único, CC, na forma aqui sugerida, atende a importante mediação de valores constitucionais relevantes.

\section{CONCLUSÃO}

A redução equitativa de indenização no Brasil, presente nos arts. 944, e 928, parágrafo único, ambos do Código Civil, gerou perplexidades e consequente produção substancial na doutrina, embora o uso da norma não se repita na jurisprudência. Isto porque o dispositivo atende a

38 Sobre o assunto, MULHOLLAND, C. A responsabilidade civil da pessoa com deficiência psíquica e/ou intelectual..., p. 633-661.

39 BARBOZA, H. H. e ALMEIDA, V. Reconhecimento, inclusão e autonomia da pessoa com deficiência: novos rumos na proteção dos vulneráveis. In: BARBOZA, H. H., MENDONÇA, B. L. de; ALMEIDA JÚNIOR, V. de A. (Coord.). O Código Civil e o Estatuto da Pessoa com Deficiência. Rio de Janeiro: Processo, 2017. p. 1-30.

${ }_{40}$ Perceba-se situação diferente daquela do menor, que tem os pais como responsáveis eleitos e impostos pela lei. Diferente o caso da pessoa com deficiência sem curador, existindo até mesmo incentivo do ordenamento jurídico para que ela viva sua autonomia desta forma. 
ultrapassada reivindicação doutrinária, a qual ainda se centrava na análise do ato ilícito para determinação do dever de indenizar.

O giro copernicano, segundo o qual a matéria passa a pensar-se sobre o prisma da reparação do lesado, tendo como protagonistas a reparação integral e as hipóteses de responsabilidade objetiva colocam a prova os dispositivos. Conforme esta posição, observou-se que parte da doutrina buscou a harmonização destas normas à axiologia constitucional do ordenamento jurídico brasileiro, apontando como seu fundamento a proteção do patrimônio mínimo e a garantia do mínimo existencial.

Contudo, problematizou-se o referido posicionamento, mesmo reconhecendo legítimas suas pretensões. Afinal, outra disciplina, a qual se trata no Brasil de forma assistemática e pouco atenciosa, apresenta ferramentas para enfrentar a questão de efetivar proteção a devedores no momento da excussão de seu patrimônio, qual seja, a responsabilidade patrimonial. Realizar a quantificação da indenização a menor na responsabilidade civil, por haver falta de patrimônio para o ofensor adimplir com o valor integral, é subtrair a análise do patrimônio às normas a que se submete.

Demonstrou-se a estrutura da responsabilidade patrimonial, a qual atua no momento de execução do crédito constituído em sentença. Após esta explicação inicial, conclui-se pela suficiência de seu regramento, por atender ao resguardo do patrimônio de dignidade e proteger, efetivamente, o devedor-ofensor. Nestes termos, torna-se redundante reduzir a indenização de forma equitativa.

Mais do que isso, alertou-se que as indenizações fixadas a menor em processo individual podem mascarar a situação de insolvência, e prejudicar a coletividade de credores no recebimento de crédito daqueles que se encontram superendividados, havendo em seu patrimônio passivo maior do que $o$ ativo. Ainda se atentou para aquelas situações em que a indenização se fixa em comodidade ao pagamento dos demais créditos, porém deveria fixar-se e se pagar em sua integralidade, utilizando todo o acervo responsável do devedor para isso, por sua natureza de crédito preferencial (é o caso das indenizações por danos morais, quando não houver credor trabalhista ou alimentício).

Enfim, revisitaram-se os dispositivos do Código Civil em estudo e foram propostas formas diferentes de aplicá-los. Quanto ao art. 928, fixa-se seu sentido como regra de responsabilidade patrimonial, determinando que esta ocorra de forma subsidiária para o incapaz, na forma do parágrafo único.

Quanto ao art. 944, parágrafo único, sugeriu-se, de forma breve, uma releitura, pensada para não o reputar inconstitucional, harmonizando-o à indenização de todo dano. No caso de dano evidente e dúvida sobre a antijuridicidade da conduta adotada pelo ofensor, deverá presumir-se caso de imputação da responsabilidade, com diminuição do quantum a ser pago pelo ofensor. Constitui-se assim verdadeira regra de julgamento, e se equilibram os interesses do lesado e do lesante, quando ambos apresentem fundamento em valor relevante para o direito pátrio. Para explorar esta interpretação sugerida, utilizou-se o exemplo da responsabilidade civil da pessoa com deficiência.

\section{REFERÊNCIAS}

ALVIM, A. Da inexecução das obrigações e suas consequências. 5. ed. São Paulo: Saraiva, 1980. 
BANDEIRA, P. G. Notas sobre o parágrafo único do artigo 944 do Código Civil. Civilistica.com. Rio de Janeiro, a. 1, n. 2, jul./dez. 2012, p. 1-22.

BARBOZA, H. H. e ALMEIDA, V. Reconhecimento, inclusão e autonomia da pessoa com deficiência: novos rumos na proteção dos vulneráveis. In: BARBOZA, H. H., MENDONÇA, B. L. de; ALMEIDA JúNIOR, V. de A. (Coord.). O Código Civil e o Estatuto da Pessoa com Deficiência. Rio de Janeiro: Processo, 2017.

BUCAR, D. Função do patrimônio e reabilitação negocial do insolvente: superendividamento da pessoa humana e outros instrumentos. 2016. Tese (Doutorado em Direito). Faculdade de Direito da Universidade do Estado do Rio de Janeiro, Rio de Janeiro.

BUCAR, D. Superendividamento: por um tratamento coletivo de débitos. In: TEPEDINO, G.; MENEZES, J. B. de (Coord.). Autonomia privada, liberdade existencial e direitos fundamentais. Belo Horizonte: Fórum, 2019, p. 699-712.

CALIXTO, M. J. A culpa na responsabilidade civil: estrutura e função. Rio de Janeiro: Renovar, 2008.

CAVALIERI FILHO, S. Programa de responsabilidade civil. 11. ed. São Paulo: Atlas, 2014.

DIDIER JÚNIOR, F. Curso de direito processual civil: da prova, direito probatório, decisão, precedente, coisa julgada e tutela provisória. 13. ed. Salvador: JusPodivm, 2018.

FACCHINI NETO, E.; ANDRADE, F. S. de. Notas sobre a indenização equitativa por danos causados por incapazes: tendência ou excepcionalidade no sistema da responsabilidade civil no Direito brasileiro? Revista Brasileira de Direito Civil - RBDCivil, Belo Horizonte, v. 13, p. 93-115, jul./set. 2017.

GONÇALVES, C. R. Direito civil brasileiro: responsabilidade civil. 4. ed. São Paulo: Saraiva, 2009, v. 4.

GOMES, O. Responsabilidade civil. Atualizado por E.B. Rio de Janeiro: Forense, 2011.

GUEDES, G. S. C. O problema do nexo causal na responsabilidade civil. Rio de Janeiro: Renovar, 2005.

KONDER, C. N. A redução equitativa da indenização em virtude do grau de culpa: apontamentos acerca do parágrafo único do art. 944 do Código Civil. Revista Trimestral de Direito Civil, Rio de Janeiro, v. 29, p. 3-34, jan./mar. 2007.

MARINONI, L. G. Prova. São Paulo: Revista dos Tribunais, 2009.

MONTEIRO FILHO, C. E. R. Artigo 944 do Código Civil: o problema da mitigação do princípio da reparação integral. In: TEPEDINO, G.; FACHIN, L. E. (Org.). O direito e o tempo: embates jurídicos e utopias contemporâneas - estudos em homenagem ao professor Ricardo Pereira Lira. Rio de Janeiro: Renovar, 2008, v. 1.

MONTEIRO FILHO, C. E. R. Limites ao princípio da reparação integral no direito brasileiro. Civilistica.com. Rio de Janeiro, a. 7, n. 1, p. 1-25, 2018.

MORAES, M. C. B. Danos à pessoa humana: uma leitura civil-constitucional dos danos morais. 2. ed. Rio de Janeiro: Processo, 2017.

MONTEIRO, W. B. Curso de direito civil: direito das obrigações. Atualizado por MALUF, C. A. D.; SILVA, R. B. T da. 39. ed. São Paulo: Saraiva, 2012, v. 5. 
MULHOLLAND, C. A responsabilidade civil da pessoa com deficiência psíquica e/ou intelectual. In: MENEZES, J. B. de (Org.). Direito das pessoas com deficiência psíquica e intelectual nas relações privadas. Rio de Janeiro: Processo, 2016.

RODRIGUES, S. Direito civil: responsabilidade civil. 19. ed. São Paulo: Saraiva, 2002, v. 4.

ROSENVALD, N; FARIAS, C. C. de; BRAGA NETTO, F. P. Curso de direito civil: responsabilidade civil. 5. ed. Salvador: JusPodivm, 2018, v. 3.

SANSEVERINO, P.T.V. Princípio da reparação integral. São Paulo: Saraiva, 2010.

SCHREIBER, A. Novos paradigmas da responsabilidade civil: da erosão dos filtros de reparação à diluição dos danos. 6. ed. São Paulo: Atlas, 2015.

SILVA, D. F.; BUSTAMANTE, T. Neminem Laedere: o novo Código Civil brasileiro e a integral reparabilidade dos danos decorrentes de ato ilícito. Revista Trimestral de Direito Civil, Rio de Janeiro, v. 20, p. 247-258, out./dez. 2004.

SOUZA, E. N. Do erro à culpa na responsabilidade civil do médico. Civilistica.com, Rio de Janeiro, a. 2, n. 2, p. 1-27, 2013.

TEPEDINO, G. Premissas metodológicas para a constitucionalização do direito civil. Revista de Direito do Estado, v. 2, p. 37-53, 2006.

TEPEDINO, G. O Novo Código Civil: duro golpe na recente experiência constitucional brasileira. Revista Trimestral de Direito Civil (editorial), Rio de Janeiro, a. 2, v. 7, p. 1-3, jul./set. 2001.

TEPEDINO, G. MORAES, M. C. B.; BARBOZA, H. H. et al. Código Civil interpretado conforme a Constituição da República. Rio de Janeiro: Renovar, 2012, v. 3.

TEPEDINO, G. Notas sobre o nexo de causalidade. In: TEPEDINO, G. Temas de direito civil. Rio de Janeiro: Renovar, 2006, v. 2.

TERRA, A. M. V.; GUEDES, G. S. C. Responsabilidade civil dos pais pelos atos praticados pelos filhos menores. Revista de Direito Civil Contemporâneo, São Paulo: Revista dos Tribunais, v. 17, n. 5, p. 135-154, out./dez. 2018.

Recebido: 04.10.2019

Aprovado: 18.11 .2019

Como citar: BUCAR, Daniel; PIRES, Caio Ribeiro. Equívocos da redução equitativa: a indevida superposição de responsabilidade civil com a responsabilidade patrimonial. Revista IBERC, Minas Gerais, v. 2, n. 3, p. 1-18, set./dez. 2019. 